\title{
1. Towards sustainable urban competitiveness? The role of organizing capacity and distributed leadership
}

\section{Leo van den Berg and Luis Carvalho}

\section{INTRODUCTION: HEIGHTENED CHALLENGES FOR URBAN COMPETITIVENESS}

Sustainability is a keyword of our time. Although the attention to urban sustainability issues goes back a few decades in academic and policy discourse (Campbell, 1996), the perception of the urgency to act is now very evident. If cities have been widely acknowledged as growth and competitiveness engines of their countries (e.g., Kresl and Ietri, 2014; McCann, 2013), modern and sustainable cities are also increasingly expected to be at the forefront of the fight against climate change and other intertwined societal challenges, such as fighting poverty and improving health conditions, among many others. Moreover, it is now also increasingly clear that in order to remain competitive in economic terms, a city's economic progress has to be holistically combined with environmental and societal dimensions. This raises gigantic challenges to urban policy-making and the way cities are managed by those in charge, at a time of rising populist concerns and the need to still unlock new growth paths in places that have been left behind for too long.

There are different normative viewpoints about what sustainability means or should be (Hopwood et al., 2005), when discussing its urban facets (Bulkeley et al., 2011). These different perspectives are very important in order to frame action and align different interests (Lombardi et al., 2011). In this chapter, we take a simplified approach, looking at sustainable urban competitiveness as "a city's ability to keep growing and developing over time while fostering social cohesion and environmental quality" (Carvalho et al., 2016, p. 1). Our main interest is to reflect on the 
challenges that emerge when urban competitiveness goals and strategies become infused with sustainability dimensions and, because of that, become increasingly multidimensional and multi-stakeholder.

In particular, we focus on the role of organizing capacity and urban leadership (van den Berg et al., 1997; van den Berg and Braun, 1999) in the ability of cities to engage multiple actors and constituencies in sustainable urban competitiveness ambitions and initiatives. We draw from recent reviews and work in the field (e.g., Beer and Clower, 2014; Sotarauta, 2006; van den Berg et al., 2014; Carvalho et al., 2016) to learn from past experiences and venture into what this implies in a context in which the stakes are higher; not only because social and environmental dimensions are increasingly important, but also because economic diversification is still a fundamental cornerstone of urban and regional development (Boschma, 2017). Overall, we argue that leadership will likely remain one of the most fundamental components of a city's organizing capacity, but it must be seen as a distributed, relational feature beyond the action of heroic individuals, chief visionaries and strong mayors.

To make this point, the chapter starts by briefly reviewing the changing context for urban leadership and the key role of organizing capacity, in times in which urban development has become - perhaps more than ever before - an open-ended process. It proceeds to discuss how organizing capacity has become largely a matter of distributed urban leadership, and its implications. Then, it looks at three types of actors and urban constituencies (lead firms, knowledge institutes and civic movements) whose influence in urban competitiveness affairs has been growing in many parts of the world, looking into how to frame their involvement in urban leadership. The chapter concludes with a number of observations about distributed urban leadership in times of new societal demands.

\section{ORGANIZING CAPACITY AND THE EVOLVING CONTEXT OF URBAN COMPETITIVENESS}

One of the reasons why organizing capacity and more demanding concepts of urban leadership are needed is because the playing field for urban development has changed substantially over the last decades. For example, in Europe during most of the 20th century - when the welfare state was being built - leadership in city councils and other agencies largely focused on the implementation of visions and policies emanating from the national level (Sotarauta, 2002; Pike et al., 2006). Change was slow, and many city departments grew substantially as a reaction to the 
demands of an industry-based economy, giving rise to municipal "silos" in land planning, utility provision, infrastructure and public works, and so on. Urban leadership tended to be formal and hierarchical, and organizing urban development was more about the ability to give and follow concrete instructions and intervene in case of deviations (Bass, 1991).

The context for urban leadership started to change over the last decades of the 20th century. From the mid-1980s onwards, globalization, the diffusion of information and telecommunication technologies, greater political integration of sovereign states and the consolidation of a knowledge-based economy with heightened factor mobility dramatically increased competition between cities to attract, among others, talent, capital and investments (van den Berg and Braun, 1999). This new context had many implications for cities and urban leadership. Urban development became an open-ended process, in which urban success increasingly depended on the strategic choices of those in charge. At this time, and building on previous studies of urban growth, decline and recovery, van den Berg et al. (1997) started to discuss the notion of urban organizing capacity as an increasing fundamental "ability to enlist all actors involved and, with their help, to generate new ideas and to develop and implement a policy designed to respond to fundamental developments and create conditions for sustainable development" (van den Berg et al., 2014, p. 1).

Therefore, more than controlling, repressing or simply throwing money at problems, the ability to organize and lead urban competitiveness became much more about managing, steering and organizing interests and networks (Sotarauta, 2006; Teisman and Klijn, 2002). This implied that, on the one hand, the resources needed - for example, knowledge, funding and legitimacy - became progressively not in the sole hands of the local administration but required partnerships with public and private actors. Moreover, on the other hand, and in order to combine these resources, urban management progressively called for trust-building, social capital, mutual understanding and even experimentation. Indeed, more than coordinating stable and formal relationships, urban leadership increasingly had to deal with uncertainty, ambiguity, bargaining and compromise (Lynn et al., 2000).

Although these shifts have been recognized for about two decades, the challenges they bring are still highly contemporary and quite far from being solved. It is clear that cities are fundamental arenas to tackle the complex societal challenges of our time, such as climate change, aging, migrations, diversity and exclusion, which go hand-in-hand with rising citizen expectations and the unfolding digital revolution. All the aforementioned pose challenges to sustainable urban competitiveness. At the same time, new modes of private engagement in urban provisions - for 
example, based on notions of shared value (Porter and Kramer, 2011) promise to challenge the playing field of urban governance and power relations within cities, with firms increasingly willing to have a role in the development of local communities and to engage in urban affairs. All in all, urban dynamics became increasingly hard to predict, also as external changes can emerge fast and have very strong impacts, requiring local leaders to identify early signals, deal with ambiguity and adapt fast to new realities.

\section{ORGANIZING CAPACITY AS A MATTER OF DISTRIBUTED LEADERSHIP}

It seems self-evident that the challenging scope of contemporary urban challenges requires organizing capacity and committed leadership. However, a problem with many studies and previous accounts on urban competitiveness and change is that they tend to look at leadership as sort of a "black box," emphasizing single leaders, visionaries and influential persons (Carvalho et al., 2016; van den Berg et al., 1997; Wray, 2019) at the expense of the processes involved in leading and transforming.

Beer and Clower (2014) identified this limitation when reviewing some of the most influential perspectives of urban and regional leadership, pinpointing three key approaches. As explored by the authors, the first view on leadership - and one of the most influential - is the so-called "great person" approach. This approach links the success or failure of strategies and projects, whether in a company or in a city, to the virtues and traits of individuals, namely their charisma and capabilities. This view holds that organizations should find these people, and retain them in decision-making positions. Clearly, the political process associated with urban leadership renders this approach's applicability limited vis-à-vis firms (for example, appointing a chief executive officer); yet, translated to the context of cities, leaders would be the charismatic "visionaries" or "heroic" mayors who championed, for example, large urban transformation projects (such as Barcelona's Pasqual Maragall or Curitiba's Jaime Lerner, to name just two).

A second set of approaches relates individual leaders with the specific leadership context. These approaches suggest that different types of leaders are necessary according to the challenges they are faced with. In principle, no single person has the capacity to be a leader across the board, and leadership capacity is contingent on time, place and types of strategies. For example, in early studies of the organization of major urban development projects in European cities (e.g., van den Berg et al., 
1997) it was found that leadership was an essential enabler, but that the key individuals in charge often changed during the project, and good initiators were not necessarily as good at implementing visions and strategies. In other words, as elaborated by Beer and Clower (2014), effective urban leadership may be a temporary phenomenon and may rely on timely contributions.

A third group of perspectives on urban leadership focuses on behavior styles. Examples are the contrasts between authoritarian, democratic and laissez-faire approaches; ordinary versus heroic leaders; and socioemotional versus task-oriented (Beer and Clower, 2014). In the same vein, in the context of urban economic development, Sotarauta (2006) distinguishes between "policy generalists" (leaders with a general view of the urban policy context and trends), "persons of substance" (with deep knowledge in a concrete field) and "persons of understanding" (able to mediate interests and bridge networks).

Valuable as they are, the above-mentioned approaches tend to associate leadership with the actions of individuals. Yet, recent studies in the field of urban and regional studies have started to discuss leadership as a distributed capacity: that is, an urban-level competence emerging out of a broader network of stakeholders whose actions, in one way or another, promote urban and regional development. For example, it has been argued that "in regional economic development leadership is by definition shared $\ldots$ be they as powerful as possible, leaders can usually transform nothing major alone. Therefore, the question is not only how leaders lead their own followers, but also how they influence other leaders" (Sotarauta, 2006, p. 2). Such a way of understanding leadership has been gaining advocates in international urban policy spheres, and is arguably very important to tackle many of the intricate societal challenges faced by cities, notably in Europe (Schlappa and Neill, 2013).

In fact, distributed leadership as relational capacity largely resonates with the leadership practices observed in recent surveys of urban projects combining economic, societal and environmental objectives (van den Berg et al., 2014; Carvalho et al., 2016). In such projects, a multitude of relevant actors, with different sorts of formal and informal resources, shape leadership constellations around projects, engaging in a multitude of tasks: brokering relations, shaping partnerships, thinking "outside the box," backing projects in complex political arenas, maintaining enthusiasm, avoiding capture by interest groups and bureaucratic units, keeping experimentation going on, assuring stability, speaking different "languages," among many other actions. In the literature on sustainability transitions, successful experimentation of new solutions to pressing urban challenges also rely on these types of agentic features, and the most 
impactful ones coalesce into dense, committed and distributed networks of individuals with a stake in the initiative (Schot and Geels, 2008). There are nowadays plentiful examples of such types of agency in energy and sustainability transitions in cities, in which some of the most relevant leadership positions are actually intermediation and not command-andcontrol positions (e.g., Kivimaa, 2014; van Winden and Carvalho, 2019).

Yet, a remaining question is: under which conditions can distributed leadership emerge in cities? It is clear that just "picking" and "getting" good leaders is, in practice, a very difficult (if possible) task. There is a time dimension involved, and thus "making" leaders may also not be a feasible option. For example, while networking skills can eventually be learned, a leader's network cannot be built overnight as it requires, among others, trust and social capital. And, even if theoretically possible, "picking," "getting" or "making" leaders would likely not suffice to make leadership a truly distributed and self-sustaining capability. This is the case because urban leadership sometimes emerges in communities - for example, through passionate individuals with an individual mission to change something - and not inside formal organizations. While in formal organizations there are appointments to be made (mayor, rector, chief executive officer, council member), this is less often the case with agents who exert informal leadership. Therefore, as put by Beer and Clower (2014), there are risks that leadership roles will not be taken up, and hence a key problem for cities is not only one of poor leadership, but also one of absence of leadership, which may endanger the feasibility of more challenging urban initiatives in many cities.

In this vein, an important notion is that it is important to create space to make leadership emerge. Building on the notion of organizational slack from management studies (Cyert and March, 1963; Geiger and Makri, 2006), Beer and Clower (2014) argue that a certain degree of slack in urban management increases the ability to take risks, experiment and innovate. Many cities and local administrations are increasingly engaging with this philosophy, for example by creating "design-thinking" units and other sorts of innovation and experimentation labs, in which new solutions are tested and new local constituencies are engaged. Moreover, it is fundamental that those in charge are willing to share power and resources. This may be particularly problematic within the public administration, in which there is a well-entrenched "instinct to control and constrain, in order to provide certainty" (Miles and Trott, 2011, p. 7).

Urban leadership may thus also rely on voluntary time contributions from experienced people from outside the local government, meaning 
that enough time to work on urban development issues has to be available in different organizations. In the aftermath of austerity and budget cuts in Europe, resources are still scarce in local governments, and this may hinder the ability to foster distributed urban leadership and engage in long-term envisioning (versus solving short-term problems). Yet, this space often has to be actively created by individuals, for example by doing things differently or doing different things in order to increase the time, capabilities and room for maneuver to act on urban leadership.

\section{NEW ACTORS IN URBAN LEADERSHIP}

It is increasingly accepted that urban leadership can (and in many cases should) go beyond the action of elected representatives and city council mandates, involving "unusual suspects." In many cities, and increasingly so, urban leadership has to be discussed in the light of the actions of other influential groups of stakeholders, notably lead firms, universities and civic movements. For example, large private companies tend to have an enduring, strong influence in urban policy-making and leadership, namely by signaling future developments and economic policy needs; the same goes for universities and knowledge institutes, in cities with high shares of student population. Many lead firms and universities are increasingly ready to collaborate, influence and take a strong role in urban leadership, and the same goes for organized groups of citizens and their associations. But is that an advantage or a threat for sustainable urban competitiveness? And what can local governments do to make the most of their involvement in urban leadership?

\section{Lead Firms}

The involvement of lead firms and private companies in urban management is framed in two rather contrasting ways in the literature (see van Winden, 2013, for a review). One influential research stream looks at private companies (namely, large corporations) as purely profitmaximizing agents, which put their own short-term, self-interest above the greater, long-term urban common good. They are seen as committed to urban progress to the extent that they can reap benefits from city assets (for example, labor, land) and influence policy agendas in a way that serves their own interests (Swyngedouw et al., 2002). Under this perspective, corporate involvement in urban development has been often linked to "urban boosterism" (for example, flagship urban redevelopment projects), so that corporations can reap most of the benefits under 
the argument that the developments will create jobs and other economic multipliers in the city, in a trickledown fashion. In a different yet related way, a classic example demonstrated that the industrial elites of the German Ruhr area were powerful enough to influence the regional economic agenda in the 1970s so that they could maintain privilege (support to the declining steel industries), at the expense of delaying a much-needed economic transition (Grabher, 1993). All in all, this perspective highlights the conflict between private interests and (longterm) urban benefits, advocating against private involvement in urban leadership.

In other literature strands, however, the role of lead firms and private corporations in urban leadership is viewed rather differently. An early study about the relation between city and enterprise framed cities as the "competitive context" in which companies operate, it thus being in their own interest to improve that context in the long run (van den Berg et al., 2004); the study analyzed how European and North American corporations (for example, Boeing, Diageo, BMW, Pfizer) contributed to social improvement in their local communities (physical regeneration, crime prevention, youth unemployment) under corporate social responsibility (CSR) schemes. More recently, it has been suggested that companies are increasingly moving beyond "tokenism" and piecemeal CSR initiatives to embrace notions of shared value and societal purpose; that is, placing the community's progress at the core of a company's strategy (Porter and Kramer, 2011). Under this perspective, improving urban development is no longer a peripheral concern of the company, but integral to competing and profit-making. Thus, lead firms would have considerable incentives to support urban leadership in a way that favors the long-term prospects of both city and enterprise.

These two views represent the extreme ends of scholarly thought on the link between private involvement in urban development; yet, they call our attention to important issues when involving lead firms in strategic urban leadership. On the one hand, the potential conflicts between private interest and sustainable urban development should not be underestimated, and this calls for enhanced accountability, and more skills in the city administration and governance systems to ensure a proper system of checks and balances. Yet, on the other hand, it is also clear that many contemporary sustainable urban competitiveness challenges require the knowledge, skills and resources of private companies, many of them with authentic ambitions to improve the "competitive urban environment" in order to strengthen the company's profile.

Two contemporary examples epitomize the challenging relation between lead firms and urban leadership. One concerns the involvement 
of large private companies in the design of "smart city" strategies. For example, leading technology companies (such as software providers, telecom companies) have significant technical knowledge that can support cities in the development of new urban solutions. Yet, it is also true that many such companies envision selling proprietary solutions, which may hamper a city's resilience in the long run by causing technological lock-ins (Townsend, 2013). Thus, a smart-city strategy strongly led by lead firms risks emphasizing techno-driven visions of sustainability at the expense of more inclusive and user-driven approaches (Carvalho, 2015).

Other examples concern the involvement of companies signaling the direction for regional innovation policies. Companies are the main innovators and are well positioned to identify promising market and innovation opportunities, hence the argument to involve them to the full. However, lead companies also have large incentives to influence policies to fit their own interests, which makes the involvement of companies in innovation policy a very challenging issue in cities and regions with weaker economic and industrial bases, in which the dominance of vested interests is a latent threat (Boschma, 2013).

\section{Knowledge Institutes}

The involvement of universities and knowledge institutes in urban leadership is much less contested in the literature: it is often seen as positive (Russo et al., 2007; van Winden, 2012), perhaps due to their typical not-for-profit nature. As urban economies become increasingly knowledge-intensive, the role of universities and their influence in urban development has grown. Just like firms, universities and research institutes are well positioned to spot innovative trends, and their researchers are often (yet, not always) connected to relevant business and knowledge networks, which are increasingly fundamental for urban development, economic renewal and many sorts of sustainability-oriented initiatives.

The involvement of universities in urban development issues can also be seen from a "shared value" perspective, in fields in which their interests may overlap (van Winden, 2012), for example:

- The promotion of the local and regional economy, entrepreneurship and innovation. The city has interests in new firm and job creation, exports and in enhancing the local tax base; while the university has growing interests in commercializing its research, for example through the support of incubators, science parks and knowledge transfer schemes. 
- Marketing, attractiveness and internationalization. The brand of the city and of the university often become intertwined, and both have an interest in strengthening it: for example, to attract businesses and students.

- Finding solutions to societal problems, such as urban mobility, health, inclusion and greening the city. Universities may see cities as test-beds for new applied research in these domains; while cities may benefit from universities' knowledge bases to tackle some of those pressing issues.

- Urban planning and student life. Universities have an important stake in typical urban planning actions and public provisions (for example, public spaces, mobility, housing) as they directly affect the academic population; and at the same time, cities may benefit from the involvement of students in city life (leading to cultural and economic vibrancy, political activism, and so on).

For all these reasons and overlaps, universities may exert their power and take important roles in urban leadership. However, their involvement is also not always conflict-free. For example, residents, tourists and students increasingly compete for the use of space in cities, and universities may exert their power to assure that their specific interests are met in the first place. The increase in student and scientist mobility in many parts of world, being overall a rather positive development, creates new challenges in cities - for example, in Southern Europe - as housing prices rise and displace permanent residents, who are outcompeted by the higher purchasing power of floating urban populations.

\section{Civic Movements and Public Engagement}

There is a long history of civic movements exerting influence in urban development and local politics (Arnstein, 1969). Those have been widely documented in cases of controversial urban renewal projects, but also related to NIMBY (not in my back yard) reactions against transport and environmental infrastructure (for example, wind turbines, waste treatment stations). For these reasons, it has been argued that getting social support early on is a critical variable behind successful urban development strategies (van den Berg et al., 1997, 2014).

Yet, beyond protesting and engaging in radical politics, many civic movements and their representatives are becoming increasingly embedded in urban development initiatives. In Barcelona, for example, emerging movements against housing evictions in the aftermath of the financial crisis became institutionalized and are now represented in the 
city council on a very high level (for example, through the Mayor Ada Colau, a well-known social activist). Moreover, technology is empowering and facilitating the involvement of civic movements and new unusual suspects in urban leadership. There are many examples across contemporary urban development domains. Examples are the involvement of co-operatives of citizens in producing and aggregating renewable energy; movements of citizens claiming for and championing new environmental improvements in their districts; the development of new services and "smart" software solutions for cities based on open data, freedom of information and distributed communities of information technology (IT) developers; communitarian co-working spaces; charities; time bank organization; among many other formal and informal communitarian practices.

Notably, engaging with civic and grassroots movements is easier said than done. Contrary to lead firms and knowledge institutes, civic movements are often unstable, distributed, and their representatives are not always easy to find, calling for new ways to engage and involve them in urban leadership.

\section{CONCLUSION}

Cities are not short of challenges today, and the role of leadership and organizing capacity is only likely to increase in competitive, sustainable and modern cities. This chapter has reviewed a number of studies and conceptual viewpoints with an eye to providing a deeper perspective on what it takes to "lead" in order to deal with contemporary urban challenges. As argued, organizing capacity and urban leadership should increasingly be seen as distributed capacities, in which new constellations of actors are not only involved, but can also take pre-eminent leadership positions. So, how to make the most of such involvement in urban leadership?

Far from closing the debate, we would simply argue that the productive involvement of new stakeholders in urban leadership requires more - not less - skills and competences from city officials and local administrations. This is fundamental, so that cities may reap the benefits of their participation and avoid latent threats; for example, making sure that private involvement is not confused with replacement, "take-over" or privatization of a council's tasks and responsibilities. City officials need more reflexive, mediation and conflict management capacities and the ability to "speak different languages" (of business people, academics and activists). The involvement of new stakeholders in urban leadership may 
give rise to out-of-the-box initiatives, obliging city officials to step outside their comfort zones and embrace risk. In that vein, urban managers need to be able to balance risk with the need to maintain accountability for their initiatives. Yet, this also poses a challenge for other constituencies engaging in sustainable urban development affairs, as their knowledge on how the city council works is often very limited as well.

Moreover, city leaders and officials need more "urban intelligence" in order to discuss at the same level with lead firms and universities, as well as to identify and mobilize civic movements. This consists in knowing better what is going on in the city, and permanently assessing new trends, identifying new actors and the implications for a city. This may involve quantitative indicators and comparative rankings, but that is rarely enough to spot more subtle changes.

For example, some cities have put in place systematic economic trend-watching and foresight initiatives, and their staff attend conferences, meetings of informal groups, and so on, to pick up weak signals. This helps to spot new economic fields and entrepreneurs beyond "old boys' networks," and to open urban leadership to new players. Moreover, the involvement of lead firms and universities in urban leadership should go hand-in-hand with the development of systematic discussion platforms to identify and explore opportunities for "shared value" creation. For the specific case of civic and distributed grassroots movements, the role of digital tools is becoming absolutely central.

\section{REFERENCES}

Arnstein, Susan, "A ladder of citizen participation," Journal of the American Institute of Planners, Vol. 35, No. 4, 1969, pp. 216-224.

Bass, Bernard, "From transactional to transformational leadership: learning to share the vision," Organizational Dynamics, Vol. 18, No. 3, 1991, pp. 19-31.

Beer, Andrew and Terry Clower, "Mobilizing leadership in cities and regions," Regional Studies, Regional Science, Vol. 1, No. 1, 2014, pp. 5-20.

Berg, Leo van den and Erik Braun, "Urban competitiveness, marketing and the need for organising capacity," Urban Studies, Vol. 36, No. 5-6, 1999, pp. 987-999.

Berg, Leo van den, Erik Braun and Jan van der Meer, "The organising capacity of metropolitan region," Environment and Planning C, Vol. 15, No. 3, 1997, pp. 253-272.

Berg, Leo van den, Erik Braun and Alexander Otgaar, "Corporate community involvement in European and US cities," Environment and Planning C, Vol. 22, 2004, pp. 475-494. 
Berg, Leo van den, Jan van den Meer and Luís Carvalho, Cities as Engines of Sustainable Competitiveness: European Urban Policy in Practice, Aldershot: Ashgate, 2014.

Boschma, Ron, "Constructing Regional Advantage and Smart Specialization: Comparison of Two European Policy Concepts," Papers in Evolutionary Economic Geography, No. 1322, Utrecht University, Section of Economic Geography, 2013.

Boschma, Ron, "Relatedness as driver of regional diversification: a research agenda," Regional Studies, Vol. 51, No. 3, 2017, pp. 351-364.

Bulkeley, Harriet, Vanessa Castán Broto, Mike Hodson and Simon Marvin (eds), Cities and Low Carbon Transitions, London: Routledge, 2011.

Campbell, Scott, "Green cities, growing cities, just cities? Urban planning and the contradictions of sustainable development," Journal of the American Planning Association, Vol. 62, No. 3, 1996, pp. 296-312.

Carvalho, Luis, "Smart cities from scratch? A socio-technical perspective," Cambridge Journal of Regions, Economy and Society, Vol. 8, No. 1, 2015, pp. 43-60.

Carvalho, Luís, Leo van den Berg, Hazem Galal and Peter Teunisse (eds), Delivering Sustainable Competitiveness, London: Routledge, 2016.

Cyert, Richard and James March, A Behavioral Theory of the Firm, Englewood Cliffs, NJ: Prentice Hall, 1963.

Geiger, Scott and Marianna Makri, "Exploration and exploitation innovation processes: the role of organizational slack in R\&D intensive firms," Journal of High Technology Management Research, Vol. 17, No. 1, 2006, pp. 97-108.

Grabher, Gernot, "The weakness of strong ties; the lock-in of regional development in the Ruhr area," in Gernot Grabher (ed.), The Embedded Firm: On the Socioeconomics of Industrial Networks, London: Routledge, 1993, pp. 255-277.

Hopwood, Bill, Mary Mellor and Geoff O'Brien, "Sustainable development: mapping different approaches," Sustainable Development, Vol. 13, 2005, pp. 38-52.

Kivimaa, Paula, "Government-affiliated intermediary organisations as actors in system-level transitions," Research Policy, Vol. 43, No. 8, 2014, pp. 13701380.

Kresl, Peter and Daniele Ietri, Urban Competitiveness: Theory and Practice, New York: Routledge, 2014.

Lombardi, Rachel, Libby Porter, Austin Barber and Chris Rogers, "Conceptualising sustainability in UK urban regeneration: a discursive formation," Urban Studies, Vol. 48, No. 2, 2011, pp. 273-296.

Lynn, Laurence, Carolyn Heinrich and Carolyn Hill, "Studying governance and public management: challenges and prospects," Journal of Public Administration Research and Theory, Vol. 10, No. 2, 2000, pp. 233-262.

McCann, Philip, Modern Urban and Regional Economics, Oxford: Oxford University Press, 2013.

Miles, Emily and William Trott, Collaborative Working Inside Out: A Series of Personal Perspectives on Government Effectiveness, London: Institute for Government, 2011. 
Pike, Andy, Andrés Rodriguez-Pose and John Tomaney, Local and Regional Development, Abingdon: Routledge, 2006.

Porter, Michael and Mark Kramer, "The big idea: creating shared value," Harvard Business Review, Vol. 89, No. 1-2, 2011, pp. 62-77.

Russo, Antonio Paolo, Leo van den Berg and Mariangela Lavanga, "Toward a sustainable relationship between city and university: a stakeholdership approach," Journal of Planning Education and Research, Vol. 27, No. 2, 2007, pp. 199-216.

Schlappa, Hans and William Neill, Cities of Tomorrow - Action Today. URBACT II Capitalisation, From Crisis to Choice: Re-imagining the Future in Shrinking Cities, Paris: URBACT, 2013.

Schot, Johan and Frank Geels, "Strategic niche management and sustainable innovation journeys: theory, findings, research agenda, and policy," Technology Analysis and Strategic Management, Vol. 20, No. 5, 2008, pp. 537-554.

Sotarauta, Markku, "Leadership, power and influence in regional development: a tentative typology of leaders and their ways of influencing," Perspectives on Process-Based Regional Development Policy, Stockholm: Nordregio, 2002, pp. 182-207.

Sotarauta, Markku, "Where have all the people gone? Leadership in the fields of regional development," Sente Working Papers, Vol. 9, 2006, pp. 1-16.

Swyngedouw, Erik, Frank Moulaert and Arantxa Rodriguez, "Neoliberal urbanization in Europe: large-scale urban development projects and the new urban policy," Antipode, Vol. 34, No. 3, 2002, pp. 542-577.

Teisman, Geert and Erik-Hans Klijn, "Partnership arrangements: governmental rhetoric or governance scheme?," Public Administration Review, Vol. 62, No. 2, 2002, pp. 197-205.

Townsend, Andy, Smart Cities: Big Data, Civic Hackers, and the Quest for a New Utopia, New York: W.W. Norton \& Company, 2013.

Winden, Willem van, EUnivercities: City-University Cooperation to the Next Level. A Baseline Study, Paris: URBACT, 2012.

Winden, Willem van, "Delivering sustainable urban solutions: a new chapter of corporate involvement in urban management," in M.P. van Dijk, J. van der Meer and J. van den Borg (eds), From Urban Systems to Sustainable Competitive Metropolitan Regions: Essays in Honour of Leo van den Berg, Rotterdam: Erasmus University Rotterdam, 2013.

Winden, Willem van and Luís Carvalho, "Intermediation in public procurement of innovation: how Amsterdam's startup-in-residence programme connects startups to urban challenges," Research Policy, Vol. 48, No. 9, 2019, 103789 (pp. 1-11).

Wray, Ian, No Little Plans: How Government Built America's Wealth and Infrastructure, London: Routledge, 2019. 